from the first essay "On Writing Botanical Essays" is a gem of self-parody: "When I was a mere botanical neophyte, in the early spring sunshine of promise, in fact at the ripe old age of twenty, every now volume that my revered Professor commended to me and, indeed, was often kind cnough to put into my hands, seemed to me to exhale a rare, exotic perfume, a distilled fragrance, nay! the very elixir of true learning". If the botanical neophytes of today, as well as those of maturer years, can grope through the exotic perfumes exhaled by this book they will find something. But that something they will probably have thought of for themselves or have read elsewhere, at less length, in books of more substance.

Peter Barlow systematies of various Indian plants, floristics, conifer wood structure, and lastly an account of the Dehra Dun Herbarium by Professor Emeritus M. B. Raizada.

The book is set in easily readable type and cleanly printed on rather poor quality greyish paper. There are commendably few printing errors. Text-figures are excellent, but some of the plates are poor, notably those between pages 152-153 and 208-209, where alternating dark and light vertical bands make it diffieult to understand spore ornamentation. Apart from these small technical blemishes, the book is a praiseworthy production and a fitting tribute to ono who did much in a short working life to advance the cause of Indian botany.

WILLIAM S. LACEY

\section{TRIBUTE TO A BOTANIST}

\section{J. Sen Memorial Volume}

Edited by H. Santapau, A. K. Ghosh, S. K. Roy, S. Chanda and S. K. Chaudhuri. Pp. xxi+498. (J. Sen Memorial Committee and Botanical Society of Bengal: Calcutta, 1969.) Rs. 40; $\$ 10$.

INDIA has had the misfortune to lose several of its distinguished botanists in the prime of life. Birbal Sahni, FRS, died bofore he was 58; P. Maheshwari, FRS, soon after 60; and Jitendrakumar Sen, deputy director of the Botanical Survey of India, died in Deccmber 1966 at the cruelly premature age of 45 .

This book, published to perpotuate Sen's memory, begins with a tribute from John Walton, Emeritus Professor of botany in the University of Glasgow, followed by a short biography provided by Dr Sunirmal Chanda, Bose Research Institute, Calcutta. Dr Sen's publications are then listed, sixty-eight in twenty-three years, testifying to his industry. His contributions lay chiefly in the fields of palynology, palacobotany and wood histology, later turning to horticulture. Appropriately, the fifty-eight articles making up the bulk of the volume are grouped into four sections: palaeopalynology, palynology (Recent), palaeobotany and taxonomy and other topics.

Sixteen papers on palaeopalynology, chiefly from Indian authors, describe spores or pollen from the Cambrian to the Quaternary. A. K. Ghosh and A. Bose record "vascular microfossils" from North American Cambrian rock samples supplied by Professor B. F. Howell of Princeton University. The authors provide no illustrations. Without these it is difficult to evaluate their claim that "it is obvious that the vascular plants had an origin long before the Silurian period". G. O. W. Kremp and J. G. Methvin discuss the increasing problems of data retrieval in palynological roscarch and suggest that the application of computer techniques can save the situation and promote fruitful research on a world scale.

The section on Recent palynology has seven contributions: one by G. Erdtman and A. Dunbar on the fine structure of Macrozamia pollen, the rest by Indian contributors on the pollen of Scrophulariaceae, Casuarinaceae, Gardeniaceae and Sterculiaceas, and on Indian fern spores.

Of the twenty-one palacobotanical papers, eighteen are by Tndian authors and most of these deal with floras or individual taxa ranging from the Lower Gondwanas of India to the Tertiary. Of particular interest here is Manju Banerjee's paper on Senotheca, a new fructification, associated with leaves of Glossopteris taeniopteroides Feistmantel, from which cuticularized seeds were obtained by maceration. In the same section Emeritus Professor Tom M. Harris discusses the problems of naming Jurassic conifers and Dr Edna Plumstead reflects on the earlicst plant life.

The last section has fourteen papers, all by Indian authors. Subjects covered include cytology, chemotaxonomy and pharmacognosy applied to taxonomy,

\section{SPIDERS, SCORPIONS AND MITES}

\section{The Arachnids}

An Introduction. By Keith R. Snow. Pp. 84. (Routledge and Kegan Paul: London, April 1970.) 25s boards; $14 s$ paper.

THE word Arachnida has recently appeared in the syllabuses of several examining boards, and this book is a timely response to the need for more information than is contained in the ordinary textbooks.

An introductory chapter describes the general structure, outlines the physiology of the class, and ends with short diagnoses of the six orders chosen for fuller treatment. First place is then given to the Acari, which are scarcely typical arachnids, but which occupy twenty pages, or a quarter of the whole. Perhaps the economic importance of ticks and mites is held to justify this proportion. Spiders and scorpions together account for another quarter.

Dr Snow has kept prominently in mind the necds of examination candidates, and this may be taken to explain the meagre space given to the other orders. A better balance might have been obtained by shortening the glossary: readers for whom this book is meant should not need definitions of such words as lateral, marine and prey, and many others. But compression was essential, and is regrettable only when particular statements appear to be generalizations. Obviously, exceptions cannot often be mentioned, but the implication that all spiders' webs are orb-wobs should have been avoided. There are a few mistakes: for example, Fig. 18 gives a spider four lungbooks, and the remark that harvestmen mate two or three times a season is an understatement of their remarkable promiscuity.

Some readers will be surprised and others pleascd at the inclusion of Limulus, an animal which, though not a true arachnid, can undoubtedly teach us much that has not yet been learned from its study. Many, too, will appreciate the advice on fieldwork and laboratory methods.

A word of praise is due to the illustrations, admirable line drawings that show precisely all details of structure. The book, in fact, is successful as just what it set out to be--not a monograph, but a helpful introduction to a group that is beginning to receive that appreciation it has always deserved.

ThEODORE SAVORY

\section{ADRENAL PATHOLOGY}

\section{Functional Pathology of the Human Adrenal Gland}

By Thomas Symington. Pp. xvi +551 . (Livingstone: Edinburgh and London, 1969.) 200 s.

THIs book contains a wealth of information about the adronal gland as is only to be expected from its chief author, Professor T. Symington. He states that he has tried to avoid the temptation to produce just another book with a descriptive catalogue of the pathology of the 